Article

\title{
Ruthenium(II) complex catalysts bearing a 2,6-bis(tetrazolyl)pyridine ligand for the transfer hydrogenation of ketones
}

\author{
Liandi Wang a,*, Tingting Liu a,b \\ a Dalian Institute of Chemical Physics, Chinese Academy of Sciences, Dalian 116023, Liaoning, China \\ b University of Chinese Academy of Sciences, Beijing 100049, China
}

\section{A R T I C L E I N F O}

\section{Article history:}

Received 1 November 2017

Accepted 1 December 2017

Published 5 February 2018

\section{Keywords:}

2,6-Bis(tetrazolyl)pyridine

Ruthenium

Transfer hydrogenation

Ketone

Homogeneous catalysis

\section{A B S T R A C T}

Three ruthenium(II) complex catalysts bearing 2,6-bis(tetrazolyl)pyridine were synthesized, structurally characterized, and applied in the transfer hydrogenation of ketones. Their different catalytic activities were attributed to the different phosphine ligands on the 4-chloro-2,6-bis(1-( $p$-tolyl)- $1 \mathrm{H}$ tetrazol-5-yl)pyridine ruthenium(II) complexes, with that based on 1,4-bis(diphenylphosphino) butane exhibiting better catalytic activity. A variety of ketones were reduced to their corresponding alcohols with $>95 \%$ conversion.

(C) 2018, Dalian Institute of Chemical Physics, Chinese Academy of Sciences. Published by Elsevier B.V. All rights reserved.

\section{Introduction}

Nitrogen-containing ligands have been widely used in coordination chemistry and homogeneous catalysis owing to ease of manipulation and the high catalytic activity of their transition metal complexes [1-5]. Many pyridyl-based symmetric ligands, such as 2,2':6',2"-terpyridines [6-10], 2,6-bis(oxazolinyl)pyridines [11-15], 2,6-bis(imino)pyridines [16-20], and 2,6bis(pyrazoyl)pyridines [21-25] have been reported and applied in organic synthesis and homogeneous catalysis.

2,6-Bis(tetrazolyl)pyridines are pyridyl-based multidentate chelating agents containing nine $\mathrm{N}$ atoms, and their metal complexes have been applied in functional materials fabrication, coordination chemistry, and catalysis. These ligands can be used in the synthesis of luminescent materials using a self-assembly strategy. Both visible and near-infrared (IR) luminescence emissions of lanthanide cations ( $\mathrm{Pr}, \mathrm{Nd}, \mathrm{Sm}, \mathrm{Eu}, \mathrm{Tb}, \mathrm{Dy}$,
Ho, Er, Tm, and $\mathrm{Yb}$ ) can be efficiently sensitized using 2,6-bis(tetrazole)pyridine [26,27]. Furthermore, platinum(II) complexes bearing 2,6-bis(tetrazole)pyridine can be used as luminescent films, dopants for OLEDs, and to form supramolecular polymeric nanofibers [28-31]. Ruthenium complexes based on mixed ligands 2,2':6',2"-terpyridine and 2,6bis(tetrazole)pyridine have been reported and used in dye-sensitized solar cells to afford novel ruthenium dyes [32-34]. These ligands can also be coordinated with other metals, such as a reported series of homoleptic complexes of 2,6-bis(tetrazole)pyridine with $\mathrm{Co}^{\mathrm{II}}, \mathrm{Ni}^{\mathrm{II}}, \mathrm{Cu}^{\mathrm{II}}$, and $\mathrm{Zn}^{\mathrm{II}}$ [35]. Furthermore, 2,6-bis(tetrazolyl)pyridine ligands can recover trivalent minor actinides effectively and selectively from $\mathrm{HNO}_{3}$ media, while exhibiting weak or almost no extraction of trivalent lanthanides with similar chemical properties [36,37]. However, 2,6-bis(tetrazolyl)pyridine ligands have rarely been applied in catalytic reactions. In 2016, zinc polymers based on

\footnotetext{
* Corresponding author. Tel: +86-411-84379551; E-mail: wangliandi@dicp.ac.cn

DOI: 10.1016/S1872-2067(17)62994-2 | http://www.sciencedirect.com/science/journal/18722067 | Chin. J. Catal., Vol. 39 , No. 2, February 2018
} 
2,6-bis(tetrazole)pyridine with different morphologies and particle sizes were obtained and used in the cyclization of aromatic dinitriles with $\beta$-aminoalcohols as heterogeneous catalysts [38].

The transfer hydrogenation (TH) of unsaturated substrates catalyzed by transition metal complexes has attracted much attention owing to its capacity for reliable reduction using simple procedures with mild conditions and is considered a prospective alternative to direct hydrogenation [39-43]. Versatile ruthenium(II) 2-aminomethylpyridine (ampy) complexes have been reported by Baratta et al. [44-49] and demonstrated very high catalytic activity in the TH and asymmetric TH (ATH) of ketones. Moreover, Noyori ruthenium(II) complexes, containing $N$-sulfonylated 1,2-diamines as chiral ligands, have been used as efficient catalysts for the ATH of ketones and imines [50-55]. Furthermore, transition-metal complexes bearing a ligand with $\mathrm{NH}$ functionality also exhibit high catalytic activity in transfer hydrogenation reactions [56-59]. Although various ligands and their transition-metal complexes have been synthesized for $\mathrm{TH}$, the development of efficient catalytic systems is still needed. We have been interested in developing $\mathrm{N}$-heterocyclic ligands and the corresponding highly effective catalyst system for application in homogeneous catalysis. Various pyridyl-based $\mathrm{N}$-containing ligands and their ruthenium(II) complexes have been reported and applied to the TH of ketones [60-65]. Herein, we describe the synthesis and structural characterization of ruthenium(II) complexes of 4-chloro2,6-bis(1-( $p$-tolyl)-1 $H$-tetrazol-5-yl)pyridine with different phosphorus ligands and their catalytic behavior in TH reactions of ketones.

\section{Experimental}

\subsection{General considerations}

All manipulation of air- and moisture-sensitive compounds was carried out under a nitrogen atmosphere using standard Schlenk techniques. Solvents were dried and distilled prior to use according to literature methods. ${ }^{1} \mathrm{H}$ and ${ }^{13} \mathrm{C}\left\{{ }^{1} \mathrm{H}\right\}$ NMR spectra were recorded on a Bruker DRX-400 spectrometer (Bruker, Germany) and all chemical shift values are referenced to $\delta_{\mathrm{TMS}}=$ $0.00 \mathrm{ppm}$ or $\mathrm{CDCl}_{3}\left(\delta\left({ }^{1} \mathrm{H}\right), 7.26 \mathrm{ppm}\right.$ and $\left.\delta\left({ }^{13} \mathrm{C}\right), 77.16 \mathrm{ppm}\right)$. HRMS analysis was performed by the Analysis Center, Dalian University of Technology. All melting points are uncorrected. Thin-layer chromatography (TLC) analysis was performed using glass-backed plates coated with silica gel $(0.2 \mathrm{~mm})$. Flash column chromatography was performed on silica gel (200-300 mesh). All chemical reagents were purchased from commercial suppliers and used as received unless otherwise indicated.

\subsection{Preparation of ligand and ruthenium complexes}

4-Chloro-2,6-bis(1-( $p$-tolyl)-1H-tetrazol-5-yl)pyridine (2). A mixture of $N^{2}, N^{6}$-di- $p$-tolylpyridine-2,6-dicarboxamide (1) (20.0 g, $58 \mathrm{mmol}), \mathrm{PCl}_{5}(24.2 \mathrm{~g}, 116 \mathrm{mmol})$, and $\mathrm{SOCl}_{2}(120 \mathrm{~mL})$ were heated at $80{ }^{\circ} \mathrm{C}$ for $3 \mathrm{~h}$. Excess $\mathrm{SOCl}_{2}$ was removed under reduced pressure and the resulting imidoyl chloride was dis- solved in $\mathrm{CH}_{2} \mathrm{Cl}_{2}(100 \mathrm{~mL})$. This solution was then added dropwise to a stirred suspension of $\mathrm{NaN}_{3}(13.6 \mathrm{~g}, 209 \mathrm{mmol})$ in DMF $(100 \mathrm{~mL})$. After addition was completed, stirring was continued for $16 \mathrm{~h}$ at room temperature. The reaction mixture was then treated with water, the organic layer was separated and washed with water $(3 \times 200 \mathrm{~mL})$, and all volatiles were removed under reduced pressure. The resultant residue was purified by column chromatography on silica gel (eluent: petroleum ether $\left.\left(60-90{ }^{\circ} \mathrm{C}\right) / \mathrm{CH}_{2} \mathrm{Cl}_{2}=2: 1, v / v\right)$ to afford 2 as a white solid $(8.7 \mathrm{~g}$, 35\%). m.p. $247-248{ }^{\circ} \mathrm{C}$. ${ }^{1} \mathrm{H}$ NMR $\left(\mathrm{CDCl}_{3}, 400 \mathrm{MHz}, 25^{\circ} \mathrm{C}\right) \delta 8.28$ (s, $2 \mathrm{H}$, pyridyl CH), $7.11(\mathrm{~d}, 4 \mathrm{H}, J=8.2 \mathrm{~Hz})$ and $6.92(\mathrm{~d}, 4 \mathrm{H}, J=$ $8.3 \mathrm{~Hz}$ ) (both $p$-tolyl $\mathrm{CH}$ ), 2.38 (s, $6 \mathrm{H}, p$-tolyl $\left.\mathrm{CH}_{3}\right) .{ }^{13} \mathrm{C}\left\{{ }^{1} \mathrm{H}\right\} \mathrm{NMR}$ $\left(\mathrm{CDCl}_{3}, 100 \mathrm{MHz}, 25^{\circ} \mathrm{C}\right) \delta 150.7,147.1,145.8,140.6,131.8$, 129.8, 127.2, 124.8, 21.4. HRMS Calcd. for $\mathrm{C}_{21} \mathrm{H}_{16} \mathrm{ClN}$ : 429.1217; Found: 429.1212.

Ruthenium complex 3a. Under a nitrogen atmosphere, a mixture of 4-chloro-2,6-bis(1-( $p$-tolyl)-1 $H$-tetrazol-5-yl)pyridine 2 (215 mg, $0.5 \mathrm{mmol}$ ), $\mathrm{RuCl}_{2}\left(\mathrm{PPh}_{3}\right)_{3}$ ( $480 \mathrm{mg}, 0.5 \mathrm{mmol}$ ), and $\mathrm{CH}_{2} \mathrm{Cl}_{2}(40 \mathrm{~mL})$ was stirred at $40{ }^{\circ} \mathrm{C}$ for $4 \mathrm{~h}$. After cooling to ambient temperature, all volatiles were evaporated under reduced pressure. The resultant residue was purified by flash chromatography on silica gel (eluent: $\mathrm{CH}_{2} \mathrm{Cl}_{2} / \mathrm{CH}_{3} \mathrm{OH}=10: 1$, $v / v)$. Recrystallization in hexane- $\mathrm{CH}_{2} \mathrm{Cl}_{2}(3: 1, v / v)$ at room temperature gave ruthenium(II) complex $\mathbf{3 a}$ as a reddish brown solid (479 mg, 85\%). m.p. $>155{ }^{\circ} \mathrm{C} \mathrm{dec.}{ }^{1} \mathrm{H}$ NMR $\left(\mathrm{CDCl}_{3}\right.$, $400 \mathrm{MHz}, 25^{\circ} \mathrm{C}$ ) $\delta 7.56,7.40,7.33,7.27,7.13$, and 6.72 (each $\mathrm{m}$, 10:9:3:6:6:6 H, aromatic $\mathrm{CH}), 2.56\left(\mathrm{~s}, 6 \mathrm{H}, p\right.$-tolyl $\left.\mathrm{CH}_{3}\right) .{ }^{13} \mathrm{C}\left\{{ }^{1} \mathrm{H}\right\}$ $\mathrm{NMR}\left(\mathrm{CDCl}_{3}, 100 \mathrm{MHz}, 25^{\circ} \mathrm{C}\right) \delta 153.25,153.22,146.8,145.1$, $144.2,134.8,134.7,134.2,133.7,133.3,133.2,131.6,130.8$, 129.9, 129.8, 129.3, 128.7, 128.6, 128.5, 127.8, 127.7, 125.5, 125.3, 21.5. ${ }^{31} \mathrm{P}\left\{{ }^{1} \mathrm{H}\right\} \mathrm{NMR}\left(\mathrm{CDCl}_{3}, 162 \mathrm{MHz}, 25^{\circ} \mathrm{C}\right) \delta 40.4,35.0$.

Ruthenium complex $\mathbf{3 b}$. Under a nitrogen atmosphere, a mixture of 1,4-bis(diphenylphosphino)butane (512 mg, 1.2 mmol), $\mathrm{RuCl}_{2}\left(\mathrm{PPh}_{3}\right)_{3}$ (959 mg, $1.0 \mathrm{mmol}$ ), and $\mathrm{CH}_{2} \mathrm{Cl}_{2}(50 \mathrm{~mL})$ was stirred at room temperature for $2 \mathrm{~h}$. Then, 4-chloro-2,6bis(1-( $p$-tolyl)-1H-tetrazol-5-yl)pyridine 2 (429 mg, $1.0 \mathrm{mmol}$ ) was added and the mixture was stirred at $40^{\circ} \mathrm{C}$ for $4 \mathrm{~h}$. After cooling to ambient temperature, all volatiles were evaporated under reduced pressure. The resultant residue was purified by flash chromatography on silica gel (eluent: AcOEt $/ \mathrm{CH}_{3} \mathrm{OH}=5: 1$, $v / v)$. Recrystallization in hexane- $\mathrm{CH}_{2} \mathrm{Cl}_{2}(3: 1, v / v)$ at room temperature gave ruthenium(II) complex $\mathbf{3 b}$ as a reddish brown solid (754 mg, 71\%). m.p. $>180{ }^{\circ} \mathrm{C} \mathrm{dec} .{ }^{1} \mathrm{H}$ NMR $\left(\mathrm{CDCl}_{3}\right.$, $\left.400 \mathrm{MHz}, 25^{\circ} \mathrm{C}\right) \delta 7.95,7.62,7.45,7.36,7.28,7.07$ and 6.86 (each $\mathrm{m}, 4: 8: 6: 2: 4: 2: 4 \mathrm{H}$, aromatic $\mathrm{CH}$ ), 2.83, 2.37, 2.11 and 1.79 (each $\left.\mathrm{m}, 4 \times \mathrm{CH}_{2}\right), 2.57$ (s, $6 \mathrm{H}, p$-tolyl $\left.\mathrm{CH}_{3}\right) .{ }^{13} \mathrm{C}\left\{{ }^{1} \mathrm{H}\right\} \mathrm{NMR}\left(\mathrm{CDCl}_{3}\right.$, $\left.100 \mathrm{MHz}, 25{ }^{\circ} \mathrm{C}\right) \delta 153.2,145.7,144.8,144.4,136.4,136.0$, 134.0, 133.9, 132.7, 132.2, 131.8, 131.6, 131.5, 131.0, 130.2, 129.3, 129.2, 129.1, 128.1, 128.0, 125.6, 124.3, 33.0, 32.7, 29.3, 29.1, 26.1, 21.7, 20.1. ${ }^{31} \mathrm{P}\left\{{ }^{1} \mathrm{H}\right\} \mathrm{NMR}\left(\mathrm{CDCl}_{3}, 162 \mathrm{MHz}, 25^{\circ} \mathrm{C}\right) \delta$ 40.4, 33.9.

Ruthenium complex 3c. Under a nitrogen atmosphere, a mixture of 1,5-bis(diphenylphosphino)pentane (106 mg, 0.24 mmol), $\mathrm{RuCl}_{2}\left(\mathrm{PPh}_{3}\right)_{3}(193 \mathrm{mg}, 0.2 \mathrm{mmol})$, and $\mathrm{CH}_{2} \mathrm{Cl}_{2}(10 \mathrm{~mL})$ was stirred at room temperature for $2 \mathrm{~h}$. Then 4-chloro-2,6bis(1-( $p$-tolyl)-1H-tetrazol-5-yl)pyridine 2 (86 mg, $0.2 \mathrm{mmol}$ ) was added and the mixture was stirred at $40^{\circ} \mathrm{C}$ for $4 \mathrm{~h}$. After 
cooling to ambient temperature, all volatiles were evaporated under reduced pressure. The resultant residue was purified by flash chromatography on silica gel (eluent: $\mathrm{CH}_{2} \mathrm{Cl}_{2} / \mathrm{AcOEt} /$ $\left.\mathrm{CH}_{3} \mathrm{OH}=5: 5: 1, v / v\right)$. Recrystallization in hexane- $\mathrm{CH}_{2} \mathrm{Cl}_{2}(3: 1$, $v / v$ ) at room temperature gave ruthenium(II) complex $3 \mathbf{c}$ as a reddish brown solid (154 mg, 74\%). m.p. $>193{ }^{\circ} \mathrm{C}$ dec. ${ }^{1} \mathrm{H}$ NMR $\left(\mathrm{CDCl}_{3}, 400 \mathrm{MHz}, 2{ }^{\circ} \mathrm{C}\right) \delta 7.87,7.58,7.44,7.38,7.30,7.23,6.96$, and 6.74 (each $\mathrm{m}, 4: 8: 2: 4: 2: 4: 2: 4 \mathrm{H}$, aromatic $\mathrm{CH}$ ), $2.52(\mathrm{~s}, 6 \mathrm{H}$, p-tolyl $\mathrm{CH}_{3}$ ), 2.44, 2.17, 1.92, 1.66, and 1.46 (each $\mathrm{m}, 5 \times \mathrm{CH}_{2}$ ). ${ }^{13} \mathrm{C}\left\{{ }^{1} \mathrm{H}\right\} \mathrm{NMR}\left(\mathrm{CDCl}_{3}, 100 \mathrm{MHz}, 25{ }^{\circ} \mathrm{C}\right) \delta 153.1,145.3,145.0$, 144.3, 136.0, 135.6, 133.9, 133.8, 131.7, 130.8, 130.0, 129.0, 128.9, 128.8, 127.9, 127.8, 125.4, 123.9, 27.6, 27.3, 26.5, 26.33, 26.26, 26.2, 21.5, 19.85, 19.79, 19.7. ${ }^{31} \mathrm{P}\left\{{ }^{1} \mathrm{H}\right\} \mathrm{NMR}\left(\mathrm{CDCl}_{3}, 162\right.$ $\left.\mathrm{MHz}, 25^{\circ} \mathrm{C}\right) \delta 41.8,32.2$.

\subsection{General procedure for TH of ketones catalyzed by 3}

Under a nitrogen atmosphere, a mixture of ketone ( $2 \mathrm{mmol})$, catalyst $3(0.01 \mathrm{mmol})$, and 2-propanol $(18 \mathrm{~mL})$ was stirred at $82{ }^{\circ} \mathrm{C}$ for $10 \mathrm{~min}$. Then, $i$ PrOK solution in 2-propanol $(2.0 \mathrm{~mL}$, $0.1 \mathrm{~mol} / \mathrm{L}, 0.2 \mathrm{mmol}$ ) was introduced to initiate the reaction. The reaction mixture was stirred at reflux. After the stated time, $0.1 \mathrm{~mL}$ of the reaction mixture was sampled and immediately diluted with $0.5 \mathrm{~mL}$ of 2-propanol precooled to $0{ }^{\circ} \mathrm{C}$, and filtered through a short pad of celite to quench the reaction by removing the complex catalyst. The resultant filtrate was used for GC analysis. After the reaction was finished, the mixture was condensed under reduced pressure and subjected to flash silica gel column chromatography to afford the alcohol product. The alcohol products were identified by comparison with authentic samples using NMR and GC analyses.

\section{Results and discussion}

A mixture of $N^{2}, N^{6}$-di- $p$-tolylpyridine-2,6-dicarboxamide 1, $\mathrm{PCl}_{5}$, and $\mathrm{SOCl}_{2}$ were heated to afford an imidoyl chloride. The ligand, 4-chloro-2,6-bis(1-( $p$-tolyl)-1 $H$-tetraz-ol-5-yl)pyridine 2, was then obtained by cycloaddition of the imidoyl chloride to $\mathrm{NaN}_{3}$ in DMF. Treatment of ligand 2 with ruthenium compounds in $\mathrm{CH}_{2} \mathrm{Cl}_{2}$ gave complexes 3a-c under reaction conditions (iii) or (iv) (Scheme 1). Due to cyclic tension, complexes 3 with 2, 3, or 6-carbon alkyl chains between the two phosphorus ligands were not obtained under the same conditions. Complexes 3a-c were stable when exposed to air at ambient temperature.

The structures of complexes $\mathbf{3}$ were supported by NMR analysis in solution. The chemical shifts of the pyridyl $\mathrm{CH}$ hydrogen atoms in complexes 3 were shifted upfield by $0.3-0.7$ ppm in the proton NMR spectrum compared with those of ligand precursor 2. Complexes 3a-c showed two signals in the ${ }^{31} \mathrm{P}\left\{{ }^{1} \mathrm{H}\right\}$ NMR spectra, suggesting that the two phosphorous groups were positioned in different environments. Single crystals of 3b suitable for X-ray crystallographic study were obtained to further validate the complex structure [66]. In the solid state, the cationic metal center of complex $\mathbf{3 b}$ was surrounded by tridentate NNN ligand 2, two $\mathrm{PPh}_{2}$ ligands, and a chloride anion, with another dissociated chloride anion in the

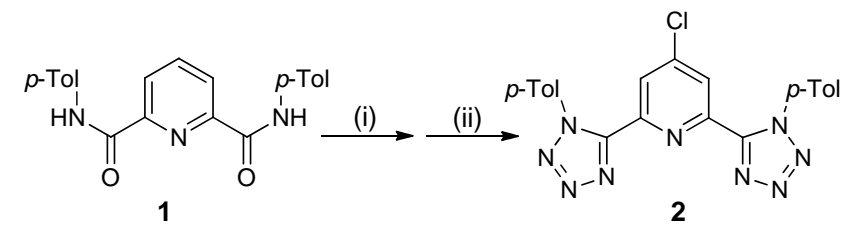

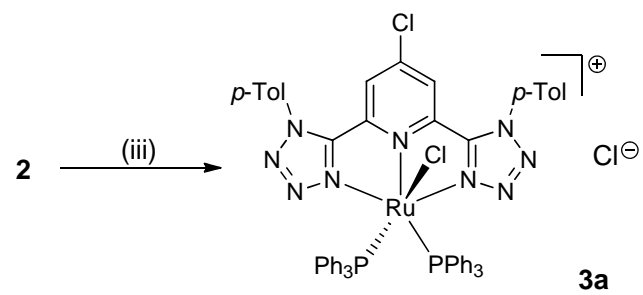

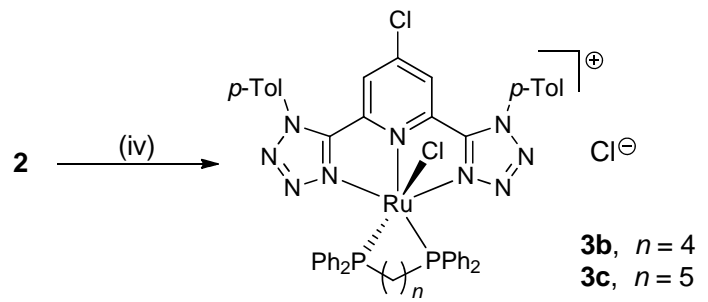

Scheme 1. Synthesis of ligand 2 and complexes 3a-c. Conditions: (i) $\mathrm{PCl}_{5}, \mathrm{SOCl}_{2}, 80^{\circ} \mathrm{C}, 3 \mathrm{~h}$; (ii) $\mathrm{NaN}_{3}, \mathrm{CH}_{2} \mathrm{Cl}_{2}, \mathrm{DMF}, \mathrm{rt}, 16 \mathrm{~h}$; (iii) $\mathrm{RuCl}_{2}\left(\mathrm{PPh}_{3}\right)_{3}$, $\mathrm{CH}_{2} \mathrm{Cl}_{2}, \mathrm{~N}_{2}(0.1 \mathrm{MPa}), 40{ }^{\circ} \mathrm{C}, 4 \mathrm{~h}$; (iv) $\mathrm{RuCl}_{2}\left(\mathrm{PPh}_{3}\right)_{3}$, dppb or dpppe, $\mathrm{CH}_{2} \mathrm{Cl}_{2}, \mathrm{~N}_{2}(0.1 \mathrm{MPa}), 40^{\circ} \mathrm{C}, 4 \mathrm{~h}$.

vicinity (Fig. 1). The $\mathrm{P}(1)-\mathrm{Ru}-\mathrm{P}(2)$ angle in $\mathbf{3 b}$ was $92.54(3)^{\circ}$, suggesting that the two $\mathrm{PPh}_{2}$ ligands were almost orthogonal to each other. $\mathrm{P}(1)$ and $\mathrm{Cl}(1)$ were almost linear to each other $\left(\mathrm{P}(1)-\mathrm{Ru}-\mathrm{Cl}(1), 171.32(3)^{\circ}\right)$ and positioned on two sides of the ligand plane. The presence of three $\mathrm{Ru}-\mathrm{N}$ bonds (2.058(2), 2.079(2), and 2.096(2) $\AA$ ), two Ru-P bonds (2.3186(8) and $2.3467(9) \AA)$, an $\mathrm{Ru}-\mathrm{Cl}$ bond $(2.4538(8) \AA)$, a N(5)-Ru-P(2) angle of $171.79(6)^{\circ}$, and a $\mathrm{P}(1)-\mathrm{Ru}-\mathrm{Cl}(1)$ angle of $171.32(3)^{\circ}$

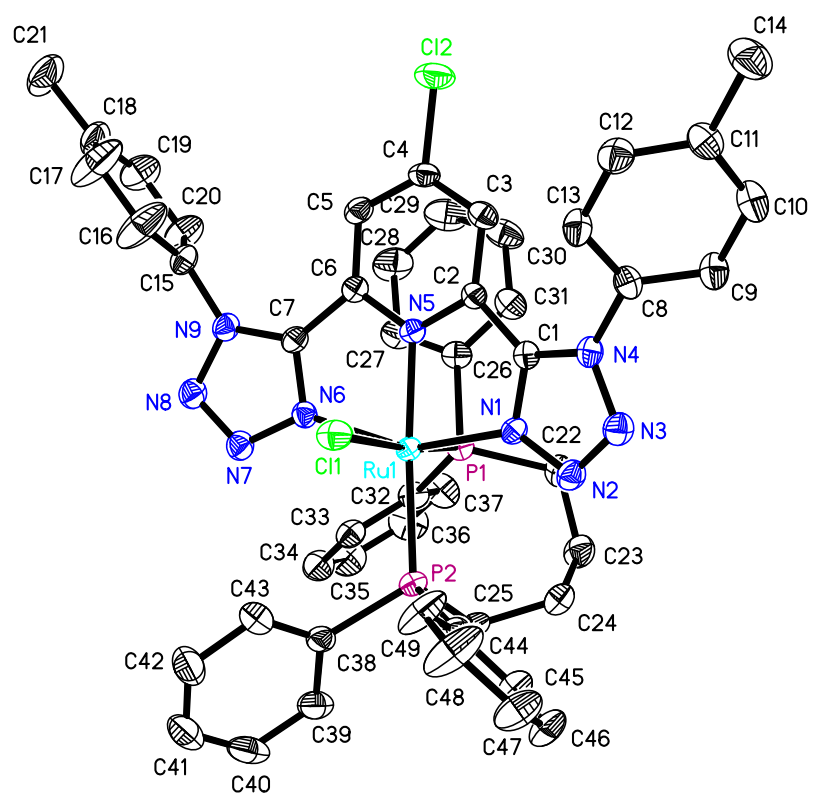

Fig. 1. Molecular structure of $\mathbf{3 b}$ with a $\mathrm{H}_{2} \mathrm{O}$ molecule and chloride anion omitted for clarity. 
identified a six-coordinate metal center in complex $\mathbf{3 b}$ with a distorted bipyramidal environment.

Ruthenium(II) complexes 3a-c were tested as catalysts in the TH of ketones (Table 1). Using $0.5 \mathrm{~mol} \%$ of 3 as catalyst, with a molar ratio of 200/20/1 for ketone/base/catalyst and $i$ PrOK as the base promoter, transfer hydrogenation of acetophenone was conducted in 2-propanol at $82{ }^{\circ} \mathrm{C}$. To achieve $>96 \%$ yield, corresponding complexes $\mathbf{3 a}, \mathbf{3 b}$ and $\mathbf{3 c}$ were reacted for 1,1 , and $2 \mathrm{~h}$, respectively (Table 1 , entries $1-3$ ). Further research into the catalyst activities was performed using 3a and 3b. For $o$-methylacetophenone, both catalysts required $3 \mathrm{~h}$ to reach $97 \%$ conversion (Table 1, entries 4 and 5). When $o$-chloroacetophenone was tested, $\mathbf{3 b}$ showed better catalytic activity, with only 20 min needed to reach $97 \%$ conversion (Table 1, entries 6 and 7). Furthermore, for cyclohexanone, $\mathbf{3 b}$ showed better catalytic activity than 3a (Table 1, entries 8 and 9). Next, $0.5 \mathrm{~mol} \% \mathbf{3 b}$ as catalyst was used in typical reactions, exhibiting very good catalytic activity for the transfer hydrogenation of $o_{-}^{-}, m-$, and $p$-chloroacetophenone and achieving
$>97 \%$ conversions for these ketones in 20-40 min (Table 1 , entries 7, 12, and 13). Electron-donating substituent-bearing aromatic ketones $o-, m$-, and $p$-methylacetophenone required a longer time to be transformed into the target reduction products (Table 1, entries 5, 10, and 11). Propiophenone, 2-acetonaphthone, 2-benzoylpyridine, and benzophenone were also smoothly reduced to their corresponding alcohols in 93\%-96\% conversions within 1-2 h (Table 1, entries 14-17). Due to the rigidity of the carbonyl rings, 1-tetralone and 9-fluorenone proceeded with the poorest reaction activity affording $70 \%$ and 83\% conversion after 2 and $0.5 \mathrm{~h}$, respectively, with extended reaction times producing no improvement (Table 1, entries 18 and 19). For the reduction of aliphatic ketones, cyclohexanone and linear 2-heptanone achieved $>95 \%$ conversions in $40 \mathrm{~min}$ and $3 \mathrm{~h}$, respectively (Table 1, entries 9 and 21), while cyclopentanone was reduced to its desired alcohol in $90 \%$ conversion in $2 \mathrm{~h}$, with no further transformation taking place when the reaction time was extended (Table 1, entry 20). The difference between the catalytic activity of complexes $\mathbf{3 a} \mathbf{a}-\mathbf{c}$ in the $\mathrm{TH}$

Table 1

Transfer hydrogenation of ketones catalyzed by complexes $\mathbf{3 a - c}$.

\begin{tabular}{|c|c|c|c|c|c|c|c|c|c|}
\hline Entry & $\mathrm{Ru}(\mathrm{II})$ cat. & Ketone & Time (h) & Yield $^{a}(\%)$ & Entry & $\mathrm{Ru}(\mathrm{II})$ cat. & Ketone & Time (h) & Yield $^{\text {a }}(\%)$ \\
\hline 1 & $3 a$ & & 1 & 97 & 12 & $3 \mathbf{b}$ & & $2 / 3$ & 98 \\
\hline 2 & $3 b$ & & 1 & 97 & 13 & $3 \mathbf{b}$ & & $1 / 2$ & 97 \\
\hline 3 & $3 c$ & & 2 & 96 & 14 & $3 \mathbf{b}$ & & 2 & 93 \\
\hline 4 & $3 a$ & & 3 & 97 & 15 & $3 \mathbf{b}$ & & 1 & 95 \\
\hline 5 & $3 \mathbf{b}$ & & 3 & 97 & 16 & $\mathbf{3 b}$ & & 1 & 96 \\
\hline 6 & $3 a$ & & 1 & 97 & 17 & $3 b$ & & 2 & 94 \\
\hline 7 & $3 b$ & & $1 / 3$ & 97 & 18 & $3 \mathbf{b}$ & & 2 & 70 \\
\hline 8 & $3 a$ & & 1 & 98 & 19 & $3 \mathbf{b}$ & & $1 / 2$ & 83 \\
\hline 9 & $3 b$ & & $2 / 3$ & 98 & 20 & $3 \mathbf{b}$ & & 2 & 90 \\
\hline 10 & $3 b$ & & 2 & 95 & 21 & $3 \mathbf{b}$ & & 3 & 97 \\
\hline 11 & $3 \mathbf{b}$ & & 2 & 93 & & & & & \\
\hline
\end{tabular}

Conditions: Ketone, $2.0 \mathrm{mmol}(0.1 \mathrm{~mol} / \mathrm{L}$ in $20 \mathrm{~mL}$ of $i \mathrm{PrOH})$; catalyst, $0.5 \mathrm{~mol} \% 3$; ketone $/$ PrOK/catalyst = 200:20:1; 0.1 $\mathrm{MPa} \mathrm{N}_{2}$, $82{ }^{\circ} \mathrm{C}$. a Determined by GC analysis. 


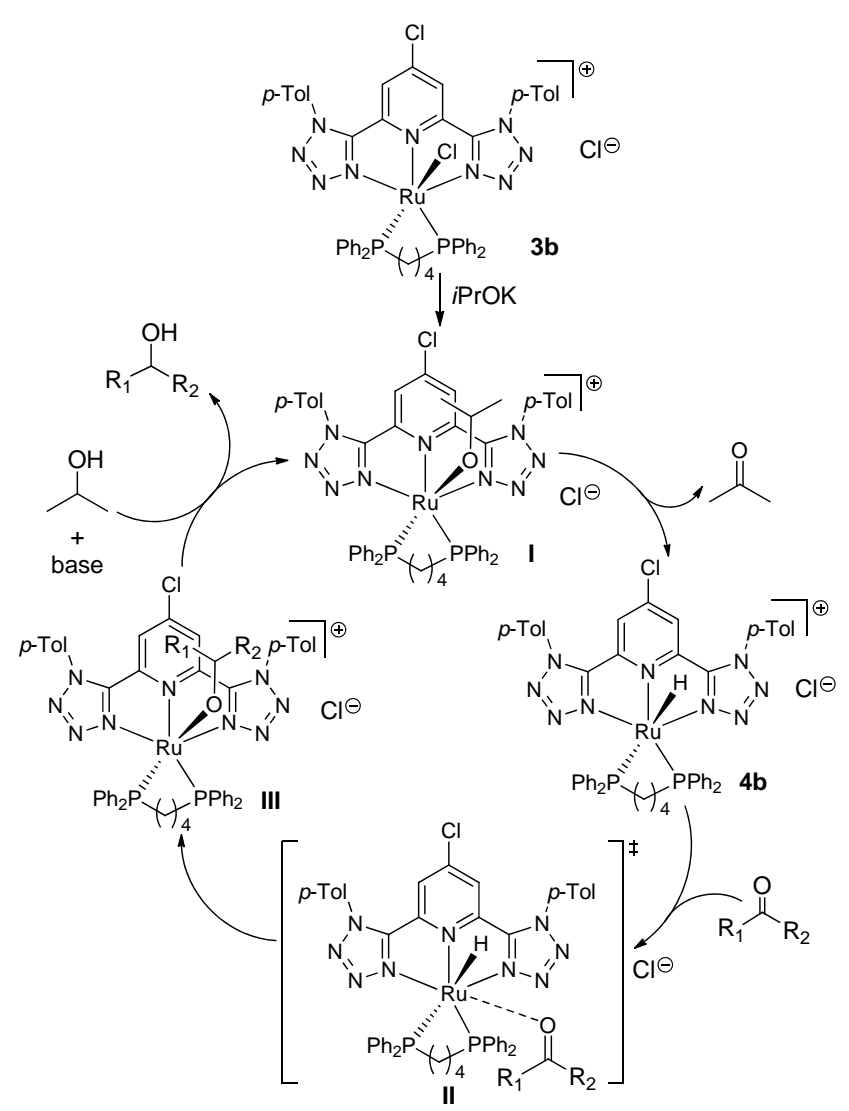

Scheme 2. A proposed mechanism.

of ketones was presumably attributed to the phosphorus ligands. These results suggested that dppb in $\mathbf{3 b}$ was more favorable for stabilizing the active catalytic species.

In the ruthenium-catalyzed transfer hydrogenation reaction of ketones, the catalytically active species is usually a $\mathrm{Ru}(\mathrm{II}) \mathrm{H}$ complex generated in situ from a $\mathrm{Ru}(\mathrm{II}) \mathrm{Cl}$ complex catalyst precursor $[49,62,64,67-70]$. To confirm the reaction mechanism, complex $\mathbf{3 b}$ was treated with $i \mathrm{PrOK}$ or $\mathrm{K}_{2} \mathrm{CO}_{3}$ in refluxing 2-propanol under a nitrogen atmosphere. The ${ }^{1} \mathrm{H}$ NMR spectrum of the inseparable product mixture showed a doublet of doublets at -6.00 ppm with ${ }^{2} J(\mathrm{H}, \mathrm{P})=107.9$ and $24.4 \mathrm{~Hz}$, which suggested the presence of $\mathrm{Ru}-\mathrm{H}$ functionality. These results implied that complexes $\mathbf{3}$ could readily generated $\mathrm{Ru}(\mathrm{II}) \mathrm{H}$ species in situ under the stated conditions. This $\mathrm{Ru}(\mathrm{II}) \mathrm{H}$ species then catalyzes the ketone reduction via a possible inner-sphere pathway (Scheme 2). Unfortunately, expected $\mathrm{Ru}(\mathrm{II}) \mathrm{H}$ complex 4b was not successfully isolated.

\section{Conclusions}

Ruthenium(II) complexes based on 2,6-bis(tetrazolyl)pyridine have been successfully synthesized, characterized by NMR and X-ray crystallographic analysis, and applied in the transfer hydrogenation of ketones. The ruthenium(II) complex based on 1,4-bis(diphenylphosphino)butane exhibited better catalytic activity, smoothly reducing various types of ketones to the corresponding alcohols with good catalytic efficiency. The present work demonstrates an efficient pyridyl-based symmetrical
$\mathrm{Ru}(\mathrm{II})$ catalyst for the transfer hydrogenation of ketones.

\section{References}

[1] W. H. Zhao, V. Ferro, M. V. Baker, Coord. Chem. Rev., 2017, 339, 1-16.

[2] S. Raoufmoghaddam, Y. P. Zhou, Y. W. Wang, M. Driess, J. Organomet. Chem., 2017, 829, 2-10.

[3] T. Ochiai, D. Franz, S. Inoue, Chem. Soc. Rev., 2016, 45, 6327-6344.

[4] X. Wang, A. X. Tian, X. L. Wang, RSC Adv., 2015, 5, 41155-41168.

[5] M. P. Carroll, P. J. Guiry, Chem. Soc. Rev., 2014, 43, 819-833.

[6] A. Arrigo, A. Santoro, F. Puntoriero, P. P. Lainé, S. Campagna, Coord. Chem. Rev., 2015, 304-305, 109-116.

[7] P. C. Dhar, P. Mohanty, Res. J. Chem. Sci., 2014, 4, 85-89.

[8] Y. Gao, D. Rajwar, A. C. Grimsdale, Macromol. Rapid Commun., 2014, 35, 1727-1740.

[9] R. Sakamoto, S. Katagiri, H. Maeda, H. Nishihara, Coord. Chem. Rev., 2013, 257, 1493-1506.

[10] A. Wild, A. Winter, F. Schlütter, U. S. Schubert, Chem. Soc. Rev., 2011, 40, 1459-1511.

[11] S. Rout, A. Das, V. K. Singh, Chem. Commun., 2017, 53, 5143-5146.

[12] K. E. Burrows, S. E. McGrath, R. Kulmaczewski, O. Cespedes, S. A. Barrett, M. A. Halcrow, Chem. Eur. J., 2017, 23, 9067-9075.

[13] A. Suneja, V. Bisai, V. K. Singh, J. Org. Chem., 2016, 81, 4779-4788.

[14] Z. H. Li, Z. J. Jiang, W. K. Su, Green Chem., 2015, 17, 2330-2334.

[15] Y. F. Liang, G. C. Fu, Angew. Chem. Int. Ed., 2015, 54, 9047-9051.

[16] P. J. Chirik, Angew. Chem. Int. Ed., 2017, 56, 5170-5181.

[17] B. Minaev, A. Baryshnikova, W. H. Sun, J. Organomet. Chem., 2016, 811, 48-65.

[18] B. L. Small, Acc. Chem. Res., 2015, 48, 2599-2611.

[19] A. Boudier, P. A. R. Breuil, L. Magna, H. Olivier-Bourbigou, P. Braunstein, Chem. Commun., 2014, 50, 1398-1407.

[20] K. G. Caulton, Eur. J. Inorg. Chem., 2012, 2012, 435-443.

[21] M. N. Magubane, G. S. Nyamato, S. O. Ojwach, O. Q. Munro, RSC Adv., 2016, 6, 65205-65221.

[22] Y. S. L. V. Narayana, M. Baumgarten, K. Müllen, R. Chandrasekar, Macromolecules, 2015, 48, 4801-4812.

[23] G. A. Craig, O. Roubeau, G. Aromí, Coord. Chem. Rev., 2014, 269, 13-31.

[24] T. D. Roberts, M. A. Little, L. J. Kershaw Cook, M. A. Halcrow, Dalton Trans., 2014, 43, 7577-7588.

[25] Y. G. Li, E. S. H. Lam, A. Y. Y. Tam, K. M. C. Wong, W. H. Lam, L. X. Wu, V. W. W. Yam, Chem. Eur. J., 2013, 19, 9987-9994.

[26] N. Wartenberg, O. Raccurt, E. Bourgeat-Lami, D. Imbert, M. Mazzanti, Chem. Eur. J., 2013, 19, 3477-3482.

[27] E. S. Andreiadis, D. Imbert, J. Pécaut, R. Demadrille, M. Mazzanti, Dalton Trans., 2012, 41, 1268-1277.

[28] M. E. Robinson, D. J. Lunn, A. Nazemi, G. R. Whittell, L. De Cola, I. Manners, Chem. Commun., 2015, 51, 15921-15924.

[29] D. K. Bhowmick, L. Stegemann, M. Bartsch, N. K. Allampally, C. A. Strassert, H. Zacharias, J. Phys. Chem. C, 2015, 119, 5551-5561.

[30] N. K. Allampally, C. A. Strassert, L. De Cola, Dalton Trans., 2012, 41, 13132-13137.

[31] C. A. Strassert, C. H. Chien, M. D. Galvez Lopez, D. Kourkoulos, D. Hertel, K. Meerholz, L. De Cola, Angew. Chem. Int. Ed., 2011, 50, 946-950.

[32] M. Duati, S. Tasca, F. C. Lynch, H. Bohlen, J. G. Vos, S. Stagni, M. D. Ward, Inorg. Chem., 2003, 42, 8377-8384.

[33] G. H. Wu, R. Kaneko, K. Sugawa, A. Islam, I. Bedja, R. K. Gupta, L. Y. Han, J. Otsuki, Dyes Pigment., 2017, 140, 354-362.

[34] G. H. Wu, R. Kaneko, Y. H. Zhang, Y. Shinozaki, K. Sugawa, A. Islam, L. Y. Han, I. Bedja, R. K. Gupta, Q. Shen, J. Otsuki, J. Power Sources, 


\section{Graphical Abstract}

Chin. J. Catal., 2018, 39: 327-333 doi: 10.1016/S1872-2067(17)62994-2

\section{Ruthenium(II) complex catalysts bearing a 2,6-bis(tetrazolyl)pyridine ligand for the transfer hydrogenation of ketones}

Liandi Wang*, Tingting Liu

Dalian Institute of Chemical Physics, Chinese Academy of Sciences; University of Chinese Academy of Sciences

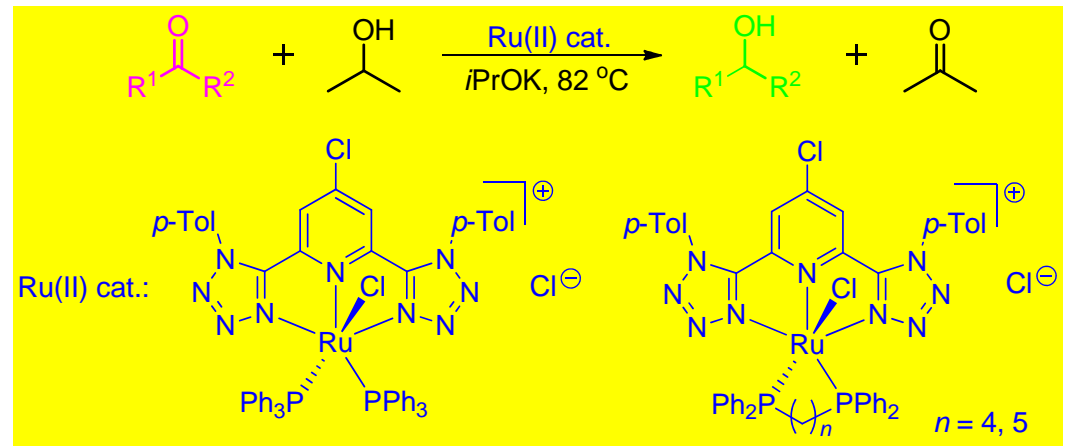

Three ruthenium(II) complex catalysts bearing 2,6-bis(tetrazolyl)pyridine were synthesized and applied in the transfer hydrogenation of ketones. Their different catalytic activities were attributed to the phosphine ligands in the 4-chloro-2,6-bis(1-( $p$-tolyl)-1H-tetrazol-5-yl)pyridine ruthenium(II) complexes. The ruthenium(II) complex based on 1,4-bis(diphenylphosphino)butane exhibited better catalytic activity, reducing a variety of ketones to their corresponding alcohols with $>95 \%$ conversion.

2016, 307, 416-425.

[35] A. Klein, A. Krest, S. Nitsche, K. Stirnat, M. Valldor, Eur. J. Inorg. Chem., 2013, 2013, 2757-2767.

[36] S. Usuda, Y. Z. Wei, R. Q. Liu, Z. Li, Y. L. Xu, Y. Wu, S. Kim, Sci. China Chem., 2012, 55, 1732-1738.

[37] I. V. Smirnov, A. V. Chirkov, V. A. Babain, E. Y. Pokrovskaya, T. A. Artamonova, Radiochim. Acta., 2009, 97, 593-601.

[38] C. Huang, H. R. Wang, X. L. Wang, K. Gao, J. Wu, H. W. Hou, Y. T. Fan, Chem. Eur. J., 2016, 22, 6389-6396.

[39] A. M. Faísca Phillips, A. J. L. Pombeiro, Org. Biomol. Chem., 2017, $15,2307-2340$

[40] D. Wang, D. Astruc, Chem. Rev., 2015, 115, 6621-6686.

[41] Y. Y. Li, S. L. Yu, W. Y. Shen, J. X. Gao, Acc. Chem. Res., 2015, 48, 2587-2598.

[42] A. Bartoszewicz, N. Ahlsten, B. Martín-Matute, Chem. Eur. J., 2013, 19, 7274-7302.

[43] F. Alonso, P. Riente, M. Yus, Acc. Chem. Res., 2011, 44, 379-391.

[44] G. Chelucci, S. Baldino, W. Baratta, Acc. Chem. Res., 2015, 48, 363-379.

[45] S. M. Zhang, W. Baratta, Organometallics, 2013, 32, 3339-3342.

[46] W. Baratta, C. Barbato, S. Magnolia, K. Siega, P. Rigo, Chem. Eur. J., 2010, 16, 3201-3206.

[47] W. Baratta, M. Ballico, G. Chelucci, K. Siega, P. Rigo, Angew. Chem. Int. Ed., 2008, 47, 4362-4365.

[48] W. Baratta, G. Chelucci, E. Herdtweck, S. Magnolia, K. Siega, P. Rigo, Angew. Chem. Int. Ed., 2007, 46, 7651-7654.

[49] W. Baratta, G. Chelucci, S. Gladiali, K. Siega, M. Toniutti, M. Zanette, E. Zangrando, P. Rigo, Angew. Chem. Int. Ed., 2005, 44, 6214-6219.

[50] B. G. Wang, H. F. Zhou, G. R. Lu, Q. X. Liu, X. L. Jiang, Org. Lett., 2017, 19, 2094-2097.

[51] T. Touge, H. Nara, M. Fujiwhara, Y. Kayaki, T. Ikariya, J. Am. Chem. Soc., 2016, 138, 10084-10087.

[52] M. Wu, T. Y. Cheng, M. Ji, G. H. Liu, J. Org. Chem., 2015, 80, 3708-3713.

[53] T. Touge, T. Hakamata, H. Nara, T. Kobayashi, N. Sayo, T. Saito, Y.
Kayaki, T. Ikariya, J. Am. Chem. Soc., 2011, 133, 14960-14963.

[54] T. Ohkuma, N. Utsumi, K. Tsutsumi, K. Murata, C. Sandoval, R. Noyori, J. Am. Chem. Soc., 2006, 128, 8724-8725.

[55] R. Noyori, S. Hashiguchi, Acc. Chem. Res., 1997, 30, 97-102.

[56] B. G. Zhao, Z. B. Han, K. L. Ding, Angew. Chem. Int. Ed., 2013, 52, 4744-4788.

[57] V. Bizet, X. Pannecoucke, J. L. Renaud, D. Cahard, Angew. Chem. Int. Ed., 2012, 51, 6467-6470.

[58] N. A. Strotman, C. A. Baxter, K. M. J. Brands, E. Cleator, S. W. Krska, R. A. Reamer, D. J. Wallace, T. J. Wright, J. Am. Chem. Soc., 2011, 133, 8362-8371.

[59] F. L. Zeng, Z. K. Yu, Organometallics, 2008, 27, 2898-2901.

[60] T. T. Liu, H. N. Chai, L. D. Wang, Z. K. Yu, Organometallics, 2017, 36, 2914-2921.

[61] H. N. Chai, Q. F. Wang, T. T. Liu, Z. K. Yu, Dalton Trans., 2016, 45, 17843-17849.

[62] H. N. Chai, T. T. Liu, Q. F. Wang, Z. K. Yu, Organometallics, 2015, 34, 5278-5284.

[63] W. M. Du, Q. F. Wang, L. D. Wang, Z. K. Yu, Organometallics, 2014, 33, 974-982.

[64] W. M. Du, L. D. Wang, P. Wu, Z. K. Yu, Chem. Eur. J., 2012, 18, 11550-11554.

[65] W. W. Jin, L. D. Wang, Z. K. Yu, Organometallics, 2012, 31, 5664-5667.

[66] CCDC 1007204 contained the supplementary crystallographic data for $\mathbf{3 b}$. Copies of this information could be obtained free of charge from the Cambridge Crystallographic Data Centre.

[67] A. Pavlova, E. Rösler, E. J. Meijer, ACS Catal., 2016, 6, 5350-5358.

[68] W. Baratta, S. Baldino, M. J. Calhorda, P. J. Costa, G. Esposito, E. Herdtweck, S. Magnolia, C. Mealli, A. Messaoudi, S. A. Mason, L. F. Veiros, Chem. Eur. J., 2014, 20, 13603-13617.

[69] C. del Pozo, M. Iglesias, F. Sánchez, Organometallics, 2011, 30, 2180-2188.

[70] J. Bosson, A. Poater, L. Cavallo, S. P. Nolan, J. Am. Chem. Soc., 2010, $132,13146-13149$. 


\title{
吡啶基桥联双四唑钉(II)配合物催化酮的转移氢化反应
}

\author{
王连弟 ${ }^{\mathrm{a},}{ }^{*}$, 刘婷婷 ${ }^{\mathrm{a}, \mathrm{b}}$ \\ a中国科学院大连化学物理研究所, 辽宁大连 116023 \\ ${ }^{\mathrm{b}}$ 中国科学院大学, 北京100049
}

摘要: 含氮配体具有稳定性好、易于合成等优点, 而且其过渡金属配合物表现出较高的催化活性, 因而在配位化学和均相 催化等研究领域受到了广泛关注. 基于吡啶骨架的三齿NNN配体具有良好的配位能力和丰富的配位模式, 如吡啶桥联的 对称配体2,2':6',2"-三吡啶、2,6-双噁唑啉基吡啶、2,6-双亚胺基吡啶和2,6-双吡唑基吡啶等在有机合成及配合物催化剂制备 等方面得到广泛应用. 2,6-双四唑基吡啶也是基于吡啶的多齿配体, 已被用于合成发光材料或高效回收次钶系元素等, 但 是其在催化领域的应用较少.

过渡金属催化的不饱和化合物的转移氢化反应具有反应条件温和、不直接使用氢气等优点, 因而受到越来越多的关 注. 一系列优异的配体及配合物在转移氢化反应中脱颖而出, 如对甲苯磺酰手性二胺配体、2-甲胺基吡啶钓配合物、配体 中含有 $\mathrm{NH}$ 官能团的过渡金属配合物等. 我们也报道了几种吡啶基桥联的含氮配体及其钓配合物, 并应用于催化酮的转移 氢化反应. 在此基础上, 本文合成了三种连有不同膦配体的2,6-双四唑基吡啶钓配合物, 并用于催化酮的转移氢化反应.

从 $N^{2}, N^{6}$-二对甲苯基-2,6-吡啶二甲酰胺(1)出发, 经氯代/环化两步反应合成4-氯吡啶基桥联双四唑化合物(2), 配体 2 与 $\mathrm{RuCl}_{2}\left(\mathrm{PPh}_{3}\right)_{3}$ 在对应的反应条件下制得三种连有不同膦配体的2,6-双四唑基吡啶钓配合物(3), 其分子结构通过核磁共振波 谱和X射线单晶晶体结构测定得到确认. 将这三种钓配合物应用于催化酮的转移氢化反应, 当催化剂用量为 $0.5 \mathrm{~mol} \%$ 时, 在异丙醇回流条件下, 比较连有不同膦配体的2,6-双四唑基吡啶钓配合物的催化活性. 膦配体为1,4-双(二苯基膦)丁烷的钉 配合物 $3 \mathbf{b}$ 表现出更高的催化活性, 含有双三苯基膦的钓配合物 $3 \mathbf{a}$ 则表现出与 $3 \mathbf{b}$ 相当或略低的催化活性, 含有1,5-双 (二苯基 膦)戊烷的钓配合物 $3 \mathbf{c}$ 活性最差. 以 $3 \mathbf{b}$ 为催化剂拓展了一系列酮底物, 取代的芳香酮、链状和环状的脂肪酮都可以高效地被 还原, 大部分酮底物以 $>95 \%$ 的转化率还原成相应的醇. 含有氯取代基的苯乙酮对反应有较大的加速作用, 反应时间更短, 转化率更高. 由于羰基环的张力, 1 -四氢菜酮与9-荡酮转化率略低.

结合实验结果与相关文献, 提出了一条基于 $\mathrm{Ru}-\mathrm{H}$ 活性中间体的内层反应机理: 钉配合物在 $i$ PrOK作用下生成Ru(II)-烷 氧基中间体I, 随后发生 $\beta-\mathrm{H}$ 消除反应脱去一分子丙酮得到 $\mathrm{Ru}-\mathrm{H}$ 配合物, Ru-H配合物与酮底物作用经过渡态 II生成另一分子 $\mathrm{Ru}(\mathrm{II})$-烷氧基中间体III, 随后异丙醇与烷氧基发生交换生成目标产物, 同时生成中间体I完成催化循环.

关键词: 2,6-双四唑基吡啶; 钉; 转移氢化; 酮; 均相催化

收稿日期: 2017-11-01. 接受日期: 2017-12-01. 出版日期: 2018-02-05.

*通讯联系人. 电话: (0411)84379551; 电子信箱: wangliandi@dicp.ac.cn

本文的电子版全文由Elsevier出版社在ScienceDirect上出版(http://www.sciencedirect.com/science/journal/18722067). 